\title{
Pengaruh Dewan Komisaris Independen dan Komite Audit terhadap Manajemen Laba pada Perusahaan Manufaktur yang Terdaftar di Bursa Efek Indonesia Tahun 2015-2017
}

\author{
Anton Ferry Ananda ${ }^{1}$ \\ Santi Andriani ${ }^{2}$ \\ Program Studi Manajemen \\ Sekolah Tinggi Ilmu Ekonomi Kertanegara Malang \\ anton_ferry@stiekma.ac.id
}

\begin{abstract}
:
This study aims to determine the effect of independent commissioners and audit committees on earnings management. This research uses quantitative methods. The data used in this study are secondary data, i.e. data obtained through existing sources and do not need to be collected by the researcher themselves. The data is in the form of an annual report issued by companies listed in the 2015-2017 period which are listed on the Indonesia Stock Exchange. The population in this study are manufacturing companies listed on the Indonesia Stock Exchange in the 2015-2017 period. The results showed that the independent board of commissioners and the audit committee had no simultaneous effect on earnings management. This is consistent with the results of the simultaneous regression coefficient test (Test F) which shows the calculated $\mathrm{F}$ value is smaller than the $\mathrm{F}$ table, and with a determinant value of $3.1 \%$. Partially the independent board of commissioners and audit committee has no effect on earnings management. Based on the results of the partial regression coefficient test ( $t$ test) on the variable independent commissioners and the audit committee showed a significance value greater than 0.05 , so it was concluded that the two variables in this study had no effect on earnings management.
\end{abstract}

Keywords: Audit Committee, Independent Board of Commissioners, Profit Management, Finance

\section{Abstrak}

Penelitian ini bertujuan untuk mengetahui pengaruh dewan komisaris independen dan komite audit terhadap manajemen laba. Penelitian ini menggunakan metode kuantitatif. Data yang digunakan dalam penelitian ini berupa data sekunder, yaitu data yang diperoleh melalui sumber yang ada dan tidak perlu dikumpulkan sendiri oleh peneliti. Data tersebut berupa laporan tahunan yang dikeluarkan oleh perusahaan tercatat periode 2015-2017 yang terdaftar di Bursa Efek Indonesia. Populasi dalam penelitian ini adalah perusahaan manufaktur yang terdaftar di Bursa Efek Indonesia pada periode 2015-2017. Hasil penelitian menunjukkan bahwa dewan komisaris independen dan komite audit tidak berpengaruh secara simultan terhadap manajemen laba. Hal tersebut sesuai dengan hasil uji koefisien regresi serentak (Uji $\mathrm{F})$ yang menunjukkan nilai $\mathrm{F}$ hitung lebih kecil dari $\mathrm{F}$ tabel, dan dengan nilai determinannya sebesar 3,1\%. Secara parsial dewan komisaris independen dan komite audit tidak berpengaruh terhadap manajemen laba. Berdasarkan hasil uji koefisien regresi parsial (uji t) pada variabel dewan komisaris independen dan komite audit menunjukkan nilai signifikasi lebih besar dari 0,05, sehingga disimpulkan kedua variabel dalam penelitian ini tidak berpengaruh terhadap manajemen laba.

Kata kunci : Komite Audit, Dewan Komisaris Independen, Manajemen Laba, Keuangan 


\section{Pendahuluan}

Laporan keuangan merupakan media atau sarana yang dibuat oleh para manajer perusahaan guna memberikan informasi keuangan maupun non keuangan kepada pihak-pihak yang memiliki kepentingan (stakeholder). Hal tersebut sesuai dengan apa yang tertera dalam PSAK No.01 yang menyatakan bahwa laporan keuangan adalah suatu penyajian terstruktur dari posisi keuangan dan kinerja keuangan suatu entitas. Pada laporan keuangan, yang biasanya dijadikan tolak ukur utama dalam mengukur kinerja manajemen adalah besarnya laba perusahaan. . Kinerja manajer tidak seharusnya dititikberatkan pada laba yang diperoleh perusahaan. Jika demikian, laba perusahaan dapat dijadikan celah oleh pihak manajer untuk melakukan tindakan menyimpang yang salah satu bentuknya adalah manajemen laba (earning management).

Para stakeholder atau pihak-pihak yang berkepentingan yang memakai data laporan keuangan tersebut, seharusnya lebih berhati-hati dan bersikap kritis dalam menilai kualitas sebuah laporan keuangan. Manajemen laba dapat diartikan sebagai salah satu faktor yang dapat mengurangi kredibilitas laporan keuangan. Tindakan manajemen laba juga mampu menambah bias dalam laporan keuangan serta mengganggu pemakai laporan keuangan yang mempercayai angka laba hasil rekayasa tersebut sebagai angka laba tanpa rekayasa. Scott (2006) mendefinisikan manajemen laba sebagai suatu cara penyajian laba yang bertujuan untuk memaksimalkan utilitas manajemen dan atau meningkatkan nilai pasar melalui pemilihan kebijakan prosedur akuntansi oleh manajemen.Selain itu manajemen laba dianggap sebagai tindakan yang dapat menurunkan kualitas laporan keuangan. Meskipun secara prinsip, praktek manajemen laba ini tidak menyalahi prinsip-prinsip akuntansi yang diterima umum, namun adanya praktek ini dapat mengikis kepercayaan masyarakat terhadap laporan keuangan eksternal dan menghalangi kompetensi aliran modal di pasar modal (Scott et al. 2001). Jika praktik manajemen laba sering dilakukan oleh manajemen, hal tersebut dapat berdampak pada menurunnya kualitas laporan keuangan perusahaan, sehingga dapat merugikan investor, kreditur, atau stakeholders lainnya karena mereka akan memperoleh informasi yang tidak sesuai dengan kenyataan.

Seperti halnya beberapa kasus yang terjadi baik di dalam maupun luar negeri yang disebabkan oleh tindakan manajemen laba, yang telah mengakibatkan skandal akuntansi yang berdampak buruk. Misalnya, seperti yang pernah terjadi pada beberapa perusahaan di Indonesia antara lain kasus PT. Indofarma Tbk, yang melakukan praktik manajemen laba dengan menyajikan overstated laba bersih dengan cara menyajikan persediaan barang yang lebih tinggi dari yang seharusnya, sehingga harga pokok penjualan tahun tersebut terjadi understated (Bapepam, 2004). Kemudian, PT Kimia Farma Tbk juga pernah terindikasi melakukan penggelembungan laba bersih tahunan senilai Rp 32,668 miliar pada tahun 2004.

Selain dua kasus tersebut masih ada banyak lagi kasus skandal akuntansi yang disebabkan oleh tindakan manajemen laba, misalnya kasus Enron Corp. yang terjadi pada tahun 2001 yang telah bekerja sama dengan KAP Arthur Anderson untuk memanipulasi laporan keuangannya. Atas kejadian tersebut tingkat kepercayaan masyarakat atas kinerja manajemen semakin terkikis dan berkurang. Dari berbagai macam contoh kasus skandal akuntansi tersebut, telah memunculkan berbagai upaya yang dapat dilakukan guna mencegah tindakan manajemen laba. Misalnya, dengan membangun sistem pengawasan dan pengendalian yang lebih baik, karena hal ini akan mendorong terciptanya keadilan, transparansi, akuntabilitas dan responsibilitas dalam pengelolaan sebuah perusahaan. 
Hal tersebut menjelaskan bahwa sangat dibutuhkan pengawasan yang efektif oleh pihak-pihak yang berkaitan dengan pengelolaan perusahaan. Salah satunya ialah dewan komisaris yang terdiri dari dewan komisaris independen. Menurut Egon Zehnder dalam FCGI (2001), dewan komisaris merupakan inti dari corporate governance yang ditugaskan untuk menjamin pelaksanaan strategi perusahaan, mengawasi manajemen dalam mengelola perusahaan serta mewajibkan terlaksananya akuntabilitas. Famadan Jensen dalam Ujiyanto dan Pramuka (2007) juga berpendapat bahwa dewan komisaris independen juga dapat bertindak sebagai penengah dalam perselisihan yang terjadi diantaraparamanajer internal dan mengawasi kebijakan manajemen, serta memberikan nasihat kepada manajemen.Selain itu, manajemen perusahaan sebagai agen juga memerlukan jasa ketiga agar tingkat kepercayaan pihak eksternal perusahaan (salah satunya principal) terhadap pertanggungjawabannya semakin tinggi, begitu pula sebaliknya pihak eksternal perusahaan memerlukan jasa pihak ketiga untuk meyakinkan dirinya bahwa laporan yang disajikan manajemen perusahaan dapat dipercaya sebagai dasar pengambilan keputusan (Martini, 2007).

Akuntan publik sebagai auditor eksternal yang relative lebih independen dari manajemen dibandingkan auditor internal, sejauh ini diharapkan dapat meminimalkan kasus rekayasa laba dan meningkatkan kredibilitas informasi akuntansi dalam laporan keuangan (Meutia, 2004). Bahkan Darmawati (2003), menyatakan keberadaan komite audit dan komisaris independen dalam suatu perusahaan juga terbukti efektif dalam mencegah praktek manajemen laba, karena keberadaan komite audit dan komisaris independen bertujuan untuk mengawasi jalannya kegiatan perusahaan. Beberapa penelitian mengenai pengaruh dewan komisaris independen dan komite audit terhadap praktik manajemen laba telah banyak dilakukan. Seperti yang dilakukan oleh Widyaningdyah (2001) yang meneliti pengaruh reputasi auditor, proporsi dewan direksi, leverage dan persentase saham yang ditawarkan kepada public pada saat IPO terhadap manajemen laba. Hasilnya menunjukkan bahwa hanya leverage yang terbukti signifikan mempengaruhi manajemen laba. Berbeda dengan Widyaningdyah (2001), Kusumaning (2004) juga menguji pengaruh proporsi dewan komisaris eksternal, leverage, komite audit, dan good governance terhadap manajemen laba. Hasilnya menunjukkan bahwa ketiga variable terbukti signifikan berpengaruh terhadap manajemen laba. Selain itu, Nabila (2013) juga pernah menguji pengaruh proporsi dewan komisaris independen, komite audit dan reputasi auditor terhadap manajeman laba. Hasil dari penelitian tersebut menyatakan bahwa hanya proporsi dewan komisaris independen saja yang menpengaruhi manajemen laba, sedangkan variabel lain tidak memiliki pengaruh sama sekali.

Penelitian lain yang dilakukan oleh Panggabean (2011) mengenai pengaruh proporsi dewan komisaris, komite audit eksternal dan kualitas auditor eksternal, menunjukkan bahwa hanya komite audit eksternal dan kualitas auditor eksternal saja yang memengaruhi manajemen laba. Sedangkan proporsi dewan komisaris tidak memiliki pengaruh terhadap manajemen laba. Berdasarkan uraian tersebut, hanya terdapat dua penelitian terdahulu yang menyatakan bahwa terdapat pengaruh antara proporsi dewan komisaris independen dan komite audit terhadap manajemen laba, sedangkan penelitian lainnya, menyatakan bahwa tidak terdapat pengaruh antara proporsi dewan komisaris independen dan komite audit terhadap manajemen laba.

\subsection{Rumusan Masalah}

1. Apakah dewan komisaris independen dan komite audit berpengaruh terhadap manajemen laba? 
2. Apakah dewan komisaris independen berpengaruh terhadap manajemen laba?

3. Apakah komite audit berpengaruh terhadap manajemen laba?

\subsection{Tujuan Penelitian}

1. Menguji pengaruh antara dewan komisaris independen dan komite audit terhadap manajemen laba

2. Menguji pengaruh dewan komisaris independen terhadap manajemen laba

3. Menguji pengaruh komite audit terhadap manajemen laba

II. Metode

\section{A. Metode Penelitian}

Penelitian ini merupakan penelitian yang akan meneliti pengaruh dewan komisaris independen dan komite audit terhadap manajemen laba. Penelitian ini menggunakan metode kuantitatif. Metode kuantitatif merupakan metode penelitian yang menggunakan proses data-data yang berupa angka sebagai alat menganalisis dan melakukan kajian penelitian, terutama mengenai apa yang sudah diteliti (Kasiram, 2008).

Bentuk penelitian pada penelitian ini adalah kausalitas menurut sugiyono (2012 : 37) yaitu hubungan yang bersifat sebab akibat yang digunakan untuk mendapatkan bukti hubungan sebab akibat, sehingga dapat diketahui mana variabel yang mempengaruhi dan mana variabel yang dipengaruhi. Penelitian ini bertujuan untuk menguji pengaruh variabel independen yaitu dewan komisaris dan komite audit terhadap variabel dependen yaitu manajemen laba. Dalam penelitian ini penulis melakukan dan mengambil data penelitian di situs Bursa Efek Indonesia yaitu www.idx.co.id. Sedangkan rencana waktu penelitian akan dilakukan pada tanggal 01 Oktober 2018 sampai dengan 28 Februari 2019. Variabel dan skala pengukuran yang terdapat dalam penelitian disajikan secara ringkas dalam tabel dibawah ini :

Tabel 1. Operasional Variabel dan Indikator

\begin{tabular}{|c|c|c|c|c|}
\hline No. & $\begin{array}{c}\text { Jenis } \\
\text { Variabel }\end{array}$ & Variabel & Definisi & Indikator \\
\hline 1. & Dependen & $\begin{array}{l}\text { Manajemen } \\
\text { Laba }\end{array}$ & $\begin{array}{l}\text { Manajemen Laba } \\
\text { didefinisikan } \\
\text { sebagai upaya } \\
\text { manajer } \\
\text { perusahaan untuk } \\
\text { mengintervensi } \\
\text { atau } \\
\text { mempengaruhi } \\
\text { informasi dalam } \\
\text { laporan keuangan } \\
\text { dengan tujuan } \\
\text { mengelabui } \\
\text { stakeholder yang } \\
\text { ingin mengetahui } \\
\text { kinerja dan kondisi } \\
\text { perusahaan }\end{array}$ & $\begin{array}{l}\text { Total akrual, pendapatan, } \\
\text { piutang dan asset. }\end{array}$ \\
\hline
\end{tabular}




\begin{tabular}{|c|c|c|c|c|}
\hline & & & (Sulistyanto, 2008). & \\
\hline 2. & Independen & $\begin{array}{l}\text { Dewan } \\
\text { Komisaris } \\
\text { Independen }\end{array}$ & $\begin{array}{l}\text { Pada Undang- } \\
\text { undang Nomor } 40 \\
\text { Tahun } 2007 \\
\text { tentang Perseroan } \\
\text { Terbatas } \\
\text { pengertian dari } \\
\text { komisaris } \\
\text { independen adalah } \\
\text { anggota dewan } \\
\text { komisaris yang } \\
\text { tidak terafiliasi } \\
\text { dengan direksi, } \\
\text { anggota dewan } \\
\text { komisaris lainnya } \\
\text { dan pemegang } \\
\text { saham pengendali, } \\
\text { serta bebas dari } \\
\text { hubungan bisnis } \\
\text { atau hubungan } \\
\text { lainnya yang dapat } \\
\text { mempengaruhi } \\
\text { kemampuannya } \\
\text { untuk bertindak } \\
\text { independen atau } \\
\text { bertindak semata- } \\
\text { mata untuk } \\
\text { kepentingan } \\
\text { perseroan. }\end{array}$ & $\begin{array}{l}\text { Jumlah anggota dewan } \\
\text { komisaris independen }\end{array}$ \\
\hline 3. & Independen & Komite Audit & $\begin{array}{l}\text { Keputusan Ketua } \\
\text { BAPEPAM Nomor: } \\
\text { Kep-29/PM/2004 } \\
\text { pengertian dari } \\
\text { komite audit } \\
\text { adalah komite yang } \\
\text { dibentuk oleh } \\
\text { dewan komisaris } \\
\text { dalam rangka } \\
\text { membantu } \\
\text { melaksanakan } \\
\text { tugas dan } \\
\text { fungsinya. }\end{array}$ & Jumlah anggota komite audit \\
\hline
\end{tabular}

Sumber: data diolah 2018

\subsection{Sumber dan Jenis Data}

Data yang digunakan dalam penelitian ini berupa data sekunder, yaitu data yang diperoleh melalui sumber yang ada dan tidak perlu dikumpulkan sendiri oleh peneliti. Data 
tersebut berupa laporan tahunan yang dikeluarkan oleh perusahaan tercatat periode 20152017 yang terdaftar di Bursa Efek Indonesia. Data-data tersebut diperoleh dari situs Bursa Efek Indonesia yaitu www.idx.co.id.

Laporan tahunan tersebut berisi informasi keuangan dan informasi non keuangan berupa informasi mengenai dewan komisaris dan komite audit. Pada penelitian ini data tersebutlah yang digunakan untuk mengetahui kondisi perusahaan jika dilihat dari sisi keuangan dan non keuangan (berdasarkan kinerja).

\subsection{Populasi dan Teknik Pengambilan Sampel}

Populasi dalam penelitian ini adalah perusahaan manufaktur yang terdaftar di Bursa Efek Indonesia pada periode 2015-2017. Sedangkan teknik pengambilan sampel dalam penelitian ini dilakukan dengan menggunakan purposive sampling, yaitu pengambilan sampel dari populasi berdasarkan suatu kriteria tertentu (Hartono, 2012 : 96). Kriteria tertentu tersebut adalah sebagai berikut:

1. Perusahaan manufaktur yang terdaftar di Bursa Efek Indonesia secara berturut-turut tahun 2015-2017.

2. Perusahaan yang memiliki data lengkap mengenai jumlah dewan komisaris, dan komite audit serta data yang diperlukan untuk mendeteksi manajemen laba.

3. Perusahaan yang tidak mengalami kerugian secara berturut-turut pada tahun 20152017. Pengambilan sampel tertera dalam tabel dibawah ini :

Tabel 2. Teknik Pengambilan Sampel

\begin{tabular}{|c|c|c|}
\hline No. & Keterangan & $\begin{array}{l}\text { Jumlah sampel } \\
\text { pengamatan }\end{array}$ \\
\hline 1. & $\begin{array}{l}\text { Perusahaan manufaktur yang terdaftar di Bursa Efek } \\
\text { Indonesia secara berturut-turut tahun 2015-2017 }\end{array}$ & 216 \\
\hline 2. & $\begin{array}{l}\text { Perusahaan yang tidak memiliki data lengkap } \\
\text { mengenai dewan komisaris dan komite audit }\end{array}$ & (93) \\
\hline 3. & $\begin{array}{l}\text { Perusahaan yang mengalami kerugian secara berturut- } \\
\text { turut }\end{array}$ & $(82)$ \\
\hline & Perusahaan yang dijadikan sampel & 41 \\
\hline & Total Perusahaan yang diambil $(41 \times 3)$ & 123 \\
\hline \multicolumn{2}{|r|}{ Sampel yang dieliminasi karena merupakan outlier } & (3) \\
\hline & Jumlah Data & 120 \\
\hline
\end{tabular}

Sumber : data sekunder yang diolah (www.idx.co.id)

\subsection{Teknik Pengumpulan Data}

Pengumpulan data yang digunakan dalam penelitian ini dilakukan dengan metode studi dokumentasi, yaitu pengumpulan data sekunder yang diperoleh dari situs resmi Bursa Efek Indonesia (www.idx.co.id). Sumber-sumber data seperti laporan tahunan perusahaan yang menjadi sampel penelitian. 


\subsection{Teknik Analisis Data}

Volume 2, Nomor 1, Agustus 2019

1. Analisis Statistik Deskriptif

Statistik deskriptif digunakan untuk mengetahui gambaran mengenai standar deviasi, rata-rata, minimum, maksimum dan variabel-variabel yang diteliti. Statsitik deskriptif mendeskripsikan data menjadi sebuah informasi yang lebih jelas dan mudah dipahami.

2. Uji Asumsi Klasik

a. Uji Normalitas

Pengujian ini dilakukan untuk apakah distribusi keseluruhan data mengikuti atau mendekati distribusi normal. Uji normalitas yang digunakan dalam penelitian ini ialah menggunakan uji Kolmogorov-Smirnov.

b. Uji Multikolinieritas

Uji ini bertujuan untuk menguji apakah di dalam model regresi terdapat korelasi antar variabel bebas. Model regresi yang baik seharusnya tidak terjadi korelasi di antara variabel bebas. Untuk mendeteksi ada atau tidaknya multikolinearitas di dalam regresi adalah melihat tolerance value dan varian inflation factor (VIF), suatu model regresi yang bebas dari masalah multikolonieritas apabila mempunyai tolerance value $>0,10$ dan nilai $\mathrm{VIF}<10$.

c. Uji heteroskedastisitas

Pengujian ini digunakan untuk menguji suatu model regresi terjadi ketidaksamaan varian dari residual dari suatu pengamatan yang lain. Model regresi yang baik adalah yang tidak terjadi heterokedastisitas. Untuk mengetahuinya digunakan grafik scatter plot, yaitu dengan melihat pola-pola tertentu pada grafik (Ghozali, 2005).

d. Uji Autokorelasi

Uji autokorelasi bertujuan untuk menguji apakah dalam suatu model regresi linier ada korelasi antara kesalahan pengganggu pada periode $t$ dengan kesalahan pada periode (t-1). Autokorelasi muncul karena observasi yang berurutan sepanjang waktu berkaitan satu sama lain. Masalah ini timbul karena residual (kesalahan pengganggu) tidak bebas dari satu observasi ke observasi yang lain. Ada beberapa cara untuk mendeteksi ada atau tidaknya autokorelasi, salah satunya adalah dengan uji Durbin- Watson (DW test). Uji Durbin Witson banyak digunakan untuk autokorelasi tingkat satu (first order autocorrelation) dan mensyaratkan adanya intersep dalam model regresi dan tidak ada autokorelasi lagi diantara variabel bebas, yang ditujukan dengan nilai D-W ada diantara nilai du dan 4-du.

3. Uji Regresi Linier Berganda

Uji regresi bertujuan untuk mengetahui bagaimana pengaruh variabel- variabel independen terhadap variabel dependen. Model yang dikembangkan dalam penelitian adalah sebagai berikut:

$D A=\alpha_{0}+\beta_{1} D K+\beta_{2} K A+e$

Dimana:

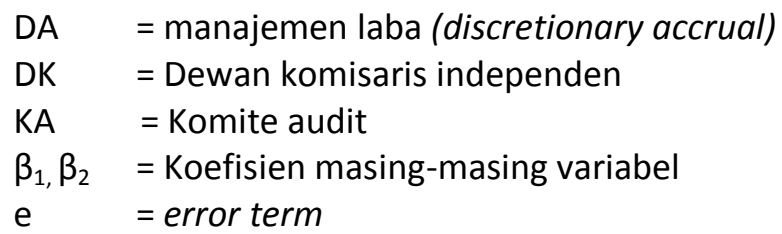


4. Uji Hipotesis

a. Uji Koefesien Determinasi $\left(R^{2}\right)$

Pengujian ini dilakukan untuk mengetahui seberapa besar prosentase sumbangan pengaruh variabel independen terhadap variabel dependen yang dinyatakan dengan koefisien determinasi $\left(R^{2}\right) \cdot R^{2}=1$ berarti variable independen berpengaruh sempurna terhadap dependent variable, sebaliknya jika $R^{2}=0$ berarti variable independent tidak berpengaruh sempurna terhadap dependent variable. Dengan kata lain, jika nilai $R^{2}$ mendekati 1 maka pengaruh variabel independen terhadap variabel dependen sangat besar. Sebaliknya, jika nilai $R^{2}$ mendekati nol maka dapat dikatakan variabel independen tidak berpengaruh terhadap variabel dependen.

b. Uji Koefesien Regresi Simultan (Uji F)

Pengujian ini dilakukan untuk mengetahui apakah variabel independen secara simultan berpengaruh terhadap variabel dependen. Jika nila $F$-hitung $>F$ table maka variabel independen secara serentak berpengaruh terhadap dependent value.

c. Pengujian Koefisien Regresi Parsial (Uji t)

Uji ini merupakan uji signifikasi (pengaruh nyata) variabel independen $(X)$ terhadap variabel dependen $(\mathrm{Y})$ secara parsial. Uji t-statistik juga berarti uji keberartian koefisien (bi). Hal ini digunakan untuk menguji koefisien regresi secara parsial dari variabel independennya.

Uji statistik $\mathrm{t}$ (t-test) dilakukan untuk memprediksi ada tidaknya pengaruh secara parsial variabel independen terhadap variabel dependen. Uji statistik $t$ pada umumnya menunjukkan seberapa jauh pengaruh satu variabel independen terhadap variabel dependennya dengan menganggap variabel independen yang lain konstan (Ghozali, 2006).

\section{Hasil dan Pembahasan}

\section{Hasil Penelitian}

Analisis Statistik Deskriptif

Tabel 3. Analisis Deskriptif

Descriptive Statistics

\begin{tabular}{|l|r|r|r|r|r|}
\hline & \multicolumn{1}{|c|}{$N$} & Minimum & Maximum & Mean & Std. Deviation \\
\hline DA & 123 & -4.472 & .558 & -.08985 & .532678 \\
DK & 123 & 20 & 50 & 35.31 & 4.323 \\
Komite_Audit & 123 & 3.00 & 4.00 & 3.3089 & .46395 \\
Valid N (listwise) & 123 & & & & \\
\hline
\end{tabular}

Sumber : data diolah menggunakan SPSS 22

Hasil analisis diskriptif tersebut diketahui nilai minimum manajemen laba (DA) adalah sebesar $-4,472$ yang menunjukkan terdapat perusahaan yang melakukan tindakan manajemen laba berupa penurunan laba (income decreasing) sekitar 4,472 dari laba yang sesungguhnya, sedangakan nilai maksimun dari DA sebesar 0,558 yang pula menunjukan terdapat perusahaan yang melakukan manajemen laba berupa peningkatan laba (income increasing) sekitar 0,558 dari nilai laba yang sesungguhnya. 
Selanjutnya, nilai mean atau rata-rata sebesar 0,08985 menunjukkan nilai manajemen laba terhadap jumlah perusahaan yang menjadi sampel ialah sebesar 0,08 , serta nilai standar deviasi dari manajemen laba (DA) sebesar 0.532678 menunjukkan rata-rata penyimpangan nilai manajemen laba (DA) terhadap rata-rata jumlah perusahaan yang terdaftar di BEl ialah sebesar 0,532.

Selain itu, diketahui dewan komisaris independen (DK) memiliki nilai minimum sebesar 20. Hal tersebut menunjukkan terdapat perusahaan yang hanya memiliki dewan komisaris independen sebesar $20 \%$ dari keseluruhan jumlah dewan komisaris yang ada. Nilai maksimum dari dewan komisaris independen sebesar 50 juga menunjukkan terdapat perusahaan yang memiliki dewan komisaris sebesar $50 \%$ dari jumlah keseluruhan dewan komisarisnya. Nilai mean sebesar 35,31 menunjukkan rata-rata dewan komisaris independen terhadap total jumlah anggota dewan komisaris adalah sebesar $35,31 \%$.

Secara umum disimpulkan terdapat beberapa perusahaan belum memenuhi ketentuan Peraturan Pencatatan Efek Nomor I - A tentang Ketentuan Umum Pencatatan Efek bersifat Ekuitas di Bursa yang menyatakan bahwa jumlah dewan komisaris independen minimum adalah sebesar $30 \%$. Pada tabel 4.5 tersebut juga menunjukkan nilai minimum komite audit (KA) sebesar 3.00 yang menunjukkan bahwa terdapat perusahaan yang memiliki dua orang anggota komite audit, sedangkan nilai maksimumnya sebesar 4.00 , menunjukkan terdapat pula perusahaan yang memiliki delapan orang komite audit. Nilai mean dari komite audit (KA) sebesar 3,3089 .

Berdasarkan uraian tersebut dapat disimpulkan, perusahaan-perusahaan sampel tersebut juga masih ada yang belum memenuhi ketentuan surat edaran Bapepam nomor SE-03/PM/2002. Dimana isi surat tersebut menyatakan jumlah dari komite audit terdiri dari sedikitnya tiga orang dan diketuai oleh komisaris independen perusahaan dengan proporsi $30 \%$ untuk tereselenggaranya pengelolaan korporasi yang baik.

\subsubsection{Evaluasi Pengujian Model}

a. Uji Normalitas Data

Sebelum melakukan uji normalitas, terlebih dahulu mengidentifikasi data outlier. Data outlier ialah data yang menyimpang terlalu jauh dari data yang lainnya dalam

Tabel 4. Hasil uji Kolmogorov-Smirnov

One-Sample Kolmogorov-Smirnov Test

\begin{tabular}{|ll|r|}
\hline & & $\begin{array}{r}\text { Unstandardiz } \\
\text { ed Residual }\end{array}$ \\
\hline Normal Parameters & & 120 \\
& Mean & .0778868 \\
Most Extreme Differences & Std. Deviation & .13592603 \\
& Absolute & .110 \\
& Positive & .110 \\
Kolmogorov-Smirnov Z & Negative & -.073 \\
Asymp. Sig. (2-tailed) & & 1.201 \\
\hline
\end{tabular}


serangkaian data. Adanya data ini akan membuat analisis terhadap serangkaian data menjadi bias, atau tidak mencerminkan fenomena yang sebenarnya. Sehingga, perlu ditentukan nilai outlier pada data variabel agar diperoleh data yang normal. Data outlier tersebut ialah:

Tabel 5. Hasil uji Variabel dependen

Casewise Diagnostics ${ }^{3}$

\begin{tabular}{|l|r|r|r|r|}
\hline $\begin{array}{l}\text { Case } \\
\text { Nu. }\end{array}$ & Std. Residual & DA & $\begin{array}{c}\text { Predicted } \\
\text { Value }\end{array}$ & Residual \\
\hline 80 & -4.310 & -2.376 & -.07413 & $-2.3018 \mathrm{E} 0$ \\
82 & -5.151 & -2.825 & -.07413 & $-2.7508 \mathrm{E} 0$ \\
121 & -8.039 & -4.472 & -.17832 & $-4.2936 \mathrm{E} 0$ \\
\hline
\end{tabular}

a. Dependent Variable: DA

Sumber : data diolah menggunakan SPSS 22

Berdasarkan tabel data tersebut diketahui data nomor 80, 82, dan 121 merupakan data outlier sehingga, harus dikeluarkan dari tabel perhitungan SPSS. Jumlah data yang semula 123 data setelah dikurangi outlier jumlah data menjadi 120 . Selanjutnya

barulah dilakukan uji normalitas yang bertujuan untuk menguji apakah keseluruhan data pada penelitian ini berdistribusi normal.

Pada uji Kolmogorov-Smirnov tersebut, diketahui besarnya nilai siknifikan adalah sebesar 0,112 dimana lebih besar dari 0,05. Hal tersebut menunjukkan keseluruhan data pada penelitian ini berdistribusi normal.

b. Uji Asumsi Klasik

1. Uji Multikolinieritas

Uji ini bertujuan untuk menguji apakah di dalam model regresi terdapat korelasi antar variabel bebas.

Tabel 5. Tabel Uji Multikolinieritas

Coefficients

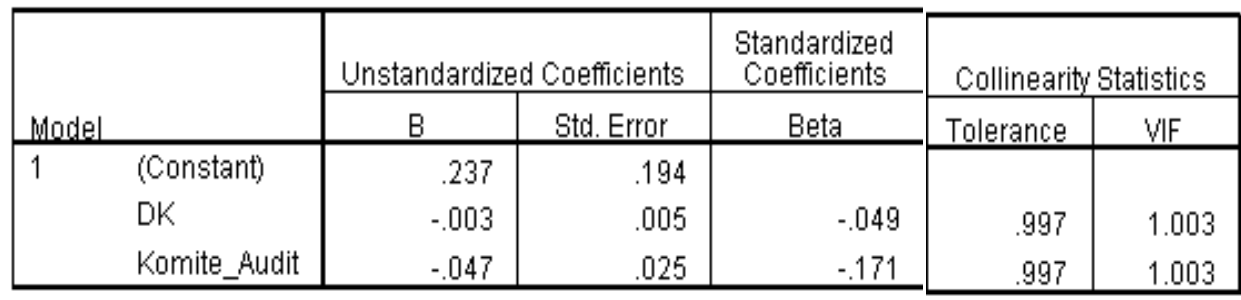

a. Dependent Variable: $\mathrm{DA}$

Sumber : data diolah menggunakan SPSS 22

Berdasarkan hasil uji multikolinieritas tersebut diketahui besarnya nilai VIF dari dewan komisaris (DK) dan komite audit sebesar 1,003 dan 1,003. Dengan demikian dinyatakan variabel independen bersifat orthogonal atau tidak terjadi korelasi satu sama lain, karena memiliki nilai VIF lebih kecil dari 10. 
2. Uji Heteroskedastisitas

Uji heteroskedastisitas bertujuan untuk menguji apakah dalam model regresi terjadi ketidaksamaan variance dan residual satu pengamatan ke pengamatan yang lain. Salah satu cara mendeteksi ada tidaknya gejala heteroskedastisitas dalam model regresi adalah dengan melakukan uji glejser. Prinsip uji heteroskedastisitas menggunakan uji glejser ini adalah dengan cara meregresikan variabel independen terhadap nilai absolute residual atau abs_res.

Tabel 6. Uji Glejser

\begin{tabular}{|c|c|c|c|c|c|c|}
\hline & & \multicolumn{5}{|c|}{ Coefficients } \\
\hline \multirow{2}{*}{\multicolumn{2}{|c|}{ Model }} & \multicolumn{2}{|c|}{ Unstandardized Coefficients } & \multirow{2}{*}{$\begin{array}{c}\begin{array}{c}\text { Standardized } \\
\text { Coefficients }\end{array} \\
\text { Beta }\end{array}$} & \multirow[b]{2}{*}{$t$} & \multirow[b]{2}{*}{ Siq. } \\
\hline & & $\mathrm{B}$ & Std. Error & & & \\
\hline \multirow[t]{3}{*}{1} & (Constant) & .270 & .155 & & 1.746 & .083 \\
\hline & DK & -.004 & .004 & -.100 & -1.086 & .280 \\
\hline & Komite_Audit & -.015 & .020 & -.066 & -.721 & .473 \\
\hline
\end{tabular}

a. Dependent Variable: Abs_res

Sumber : data diolah menggunakan SPSS 22

Uji Glejser tersebut menunjukkan nilai siknifikansi pada tabel 4.9 yaitu sebesar 0,280 dan 0,473 dimana lebih besar dari 0,05. Sehingga, dapat disimpulkan bahwa tidak terdapat masalah heterokedastisitas di dalam model

3. Uji Autokorelasi

\section{Tabel 6. Uji Run Test}

\begin{tabular}{|l|r|}
\hline \multicolumn{2}{|c}{ Runs Test } \\
\hline & $\begin{array}{c}\text { Unstandardiz } \\
\text { ed Residual }\end{array}$ \\
\hline Test Value & -.00455 \\
Cases $<$ Test Value & 60 \\
Cases $>=$ Test Value & 60 \\
Total Cases & 120 \\
Number of Runs & 61 \\
$Z$ & .000 \\
Asymp. Sig. (2-tailed) & 1.000 \\
\hline
\end{tabular}

Sumber : data diolah menggunakan SPSS 22

Dasar pengambilan keputusan dalam uji run test yaitu jika nilai Asymp. Sig. (2tailed) lebih kecil < dari 0,05 maka terdapat gejala autokorelasi dan sebaliknya jika nilai Asymp. Sig. (2-tailed) lebih besar > dari 0,05 maka tidak terdapat gejala autokorelasi. Dari hasil output diatas, diketahui nilai Asymp. Sig (2-tailed) sebesar 1,000 lebih besar > dari 0,05 maka dapat disimpulkan bahwa tidak terdapat gejala autokorelasi. 
4. Uji Regresi Linier Berganda

Uji regresi berganda dalam penelitian ini dimaksudkan untuk melihat bagaimana pengaruh dewan komisaris independen dan komite audit terhadap manajemen laba. Dengan menggunakan metode regresi linier berganda didapatkan hasil sebagai berikut:

Tabel 6. Hasil Uji Regresi Berganda

\begin{tabular}{|c|c|c|c|c|c|c|c|c|}
\hline \multicolumn{9}{|c|}{ Coefficients ${ }^{3}$} \\
\hline \multirow[b]{2}{*}{ Madel } & & \multicolumn{2}{|c|}{ Unstandardized Coefficients } & \multirow{2}{*}{$\begin{array}{c}\begin{array}{c}\text { Standardized } \\
\text { Coefficients }\end{array} \\
\text { Beta } \\
\end{array}$} & \multirow[b]{2}{*}{$t$} & \multirow[b]{2}{*}{ Siq. } & \multicolumn{2}{|c|}{ Collinearity Statistics } \\
\hline & & B & Std. Error & & & & Tolerance & VIF \\
\hline 1 & (Constant) & .237 & .194 & & 1.223 & .224 & & \\
\hline & DK & -.003 & .005 & -.049 & -.538 & .591 & .997 & 1.003 \\
\hline & Komite_Audit & -.047 & .025 & -.171 & -1.875 & .063 & .997 & 1.003 \\
\hline
\end{tabular}

a. Dependent Variable: DA

Sumber : data diolah menggunakan SPSS 22

Berdasarkan hasil pengujian regresi di atas diketahui dapat dibentuk sebuah persamaan sebagai berikut:

$\mathrm{DA}=0,237-0,003 \mathrm{DK}-0,047 \mathrm{KA}$

Persamaan tersebut dapat diartikan bahwa hanya komite audit yang berpengaruh terhadap manajemen laba sedangkan dewan komisaris independen tidak berpengaruh terhadap manajemen laba.

Arti dari persamaan angka di atas adalah sebagai berikut:

a. Nilai konstanta (a) adalah sebesar 0,237, artinya jika dewan komisaris independen (DK) dan komite audit perusahaan bernilai 0, maka manajemen laba (DA) akan bernilai 0,237.

b. Nilai koefisien regresi dari variabel dewan komisari independen (DK) bernilai 0,003 artinya ketika terjadi kenaikan $1 \%$ proporsi dewan kimoisaris independen maka dapat menurunkan nilai manajemen laba (DA) sebesar 0,003 dengan asumsi variabel lain bernilai tetap.

c. Nilai koefisien regresi dari variabel komite audit bernilai -0,047 artinya ketika terjadi kenaikan jumlah satu komite audit maka dapat menurunkan nilai manajemen laba (DA) sebesar 0,047 dengan asumsi variabel lain bernilai tetap.

\subsubsection{Uji Hipotesis}

1. Uji Determinan $\left(R^{2}\right)$

Uji determinasi adalah uji yang digunakan untuk mengetahui seberapa besar persentase pengaruh variabel independen secara keseluruhan terhadap variabel dependen. Hasil uji determinasi menghasilkan output sebagai berikut:

Tabel 6. Hasil Uji Determinan

Model Summary

\begin{tabular}{|l|l|r|r|r|}
\hline $\begin{array}{l}\text { Mode } \\
1\end{array}$ & $\mathrm{R}$ & $\mathrm{R}$ Square & $\begin{array}{c}\text { Adjusted R } \\
\text { Square }\end{array}$ & $\begin{array}{c}\text { Std. Error of } \\
\text { the Estimate }\end{array}$ \\
\hline 1 & $.175^{\mathrm{a}}$ & .031 & .014 & .127731 \\
\hline
\end{tabular}

a. Predictors: (Constant), Komite_Audit, DK 
Besarnya R Square yang ditunjukkan pada tabel tersebut adalah hanya sebesar 0,031. Hal ini menunjukkan hanya sebesar $3,1 \%$ saja variabel manajemen laba dapat dijelaskan oleh kedua variabel independen dalam penelitian ini yaitu dewan komisaris independen dan komite audit, sedangkan sebesar 96,9\% dijelaskan oleh faktor-faktor atau variabel-variabel lain di luar model.

2. Uji Koefesien Regresi Serentak (Uji F)

Uji F atau uji koefisien regresi secara serentak, bertujuan untuk mengetahui pengaruh variabel independen secara serentak terhadap variabel dependen. Uji $F$ dapat diketahui melalui uji Anova.

Tabel 8. Hasil Uji Statistik F

ANOVA ${ }^{\text {b }}$

\begin{tabular}{|c|c|c|c|c|c|c|}
\hline \multicolumn{2}{|c|}{ Madel } & $\begin{array}{c}\text { Sum of } \\
\text { Squares }\end{array}$ & $\mathrm{df}$ & Mean Square & $\mathrm{F}$ & Sig. \\
\hline 1 & Regression & .060 & 2 & .030 & 1.853 & $.161^{z}$ \\
\hline & Residual & 1.909 & 117 & .016 & & \\
\hline & Total & 1.969 & 119 & & & \\
\hline
\end{tabular}

a. Predictors: (Constant), Komite_Audit, DK

b. Dependent Variable: DA

Sumber : data diolah menggunakan SPSS 22

Berdasarkan tabel ANOVA tersebut dapat diketahui nilai $F$ hitung sebesar 1,853 dengan probabilitas sebesar 0,161 . Karena nilai $F$ hitung lebih kecil dari $F$ tabel $(3,073)$ dan nilai probabilitas lebih besar dari 0,05, maka dapat disimpulkan dalam model regresi dapat disimpulkan bahwa variabel dewan komisaris independen dan komite audit secara bersama-sama tidak berpengaruh terhadap manajemen laba.

3. Uji Koefisien Regresi Parsial (Uji t)

Uji t digunakan untuk menguji pengaruh variabel independen terhadap dependen secara parsial. Hasil pengujian hipotesis:

\section{Tabel 8. Hasil Uji t}

\begin{tabular}{|c|c|c|c|c|c|c|}
\hline \multicolumn{7}{|c|}{ Coefficients } \\
\hline \multirow[b]{2}{*}{ Made } & & \multicolumn{2}{|c|}{ Unstandardized Coefficients } & \multirow{2}{*}{ 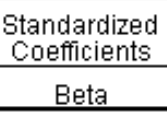 } & \multirow[b]{2}{*}{$\mathrm{t}$} & \multirow[b]{2}{*}{ Siq. } \\
\hline & & $\mathrm{B}$ & Std. Error & & & \\
\hline \multirow[t]{3}{*}{1} & (Constant) & .237 & .194 & & 1.223 & .224 \\
\hline & DK & -.003 & .005 & -.049 & -.538 & .591 \\
\hline & Komite_Audit & -.047 & .025 & -.171 & -1.875 & .063 \\
\hline
\end{tabular}

a. Dependent Variable: DA

Sumber : data diolah menggunakan SPSS 22

Hasil uji t tersebut diketahui besarnya signifikan dari dewan komisaris independen dan komite audit masing-masing 0,591 dan 0,063. Hal tersebut menunjukkan hanya dewan komisaris independen dan komite audit secara parsial tidak berpengaruh terhadap manajemen laba. Hal tersebut karena nilai signifikan dari dewan komisaris independen 
dan komite audit lebih besar dari 0,05, sehingga dapat disimpulkan variabel dewan komisaris independen dan komite audit tidak berpengaruh terhadap manajemen laba.

\subsection{Pembahasan Hasil Penelitian}

4.3.1 Dewan Komisaris Independen

Berdasarkan hasil analisis dari uji regresi linier berganda dan uji-t diketahui besarnya nilai koefisien sebesar -0,003 dan signifikan dewan komisaris independen sebesar 0,591 >0,05. Hal tersebut menunjukkan bahwa dewan komisaris independen tidak berpengaruh terhadap manajemen laba. Singkatnya, keberadaan dewan komisaris independen tidak mampu mengurangi tindakan manajemen laba pada perusahaan go public. Uraian tersebut dapat diartikan bahwa keberadaan dewan komisaris independen tidak mampu melakukan fungsi pengawasan dengan baik. Sehingga kemungkinan terjadinya tindakan manajemen laba dalam penyajian laporan keuangan yang dilakukan oleh pihak manajemen sulit diawasi maupun dikendalikan oleh dewan komisaris independen.

Hasil penelitian ini sesuai dengan penelitian Yendrawati (2015) yang mengatakan dewan komisaris yang independen tidak berpengaruh terhadap manajemen laba $\mathrm{Hal}$ ini dikarenakan pembentukan pengangkatan komisaris independen oleh perusahaan hanya memenuhi peraturan BEI tanggal 1 Juli 2000 yang menyatakan bahwa "perusahaan yang listed di Bursa harus mempunyai komisaris independen". "Di Indonesia sering terjadi anggota dewan komisaris hanya bertindak pasif bahkan sama sekali tidak menjalankan peran pengawasannya yang sangat mendasar terhadap dewan direksi. Dewan komisaris seringkali dianggap tidak memiliki manfaat. Hal ini dapat dilihat dalam fakta, bahwa banyak anggota dewan komisaris tidak memiliki kemampuan, dan tidak dapat menunjukkan independensinya" (FCGI, 2012).

\subsubsection{Komite Audit}

Berdasarkan dari hasil analisis diketahui nilai signifikan komite audit sebesar $0,063>0,05$ yang menunjukkan komite audit tidak berpengaruh terhadap manajemen laba.

Uaraian tersebut dapat disebabkan oleh kewenangan komite audit yang hanya dibatasi oleh fungsi mereka sebagai alat bantu dewan komisaris, sehingga tidak memiliki otoritas eksekusi apapun. Singkatnya, komite audit hanya mampu memberikan rekomendasi atas segala review yang telah dilakukan kepada dewan komisaris, namun segala keputusan berada pada dewan komisaris.

Sehingga perlu dibangun system pengawasan yang lebih baik bagi komite audit dalam penegelolaan perusahaan. Misalnya komite audit diberikan kewenangan unuk memberikan hukuman bagi pihak manajemen yang tidak melakukan tindakan kecurangan (fraud).

Hasil penelitian ini sama seperti penelitian Palestin (2009), Putri (2011) dan Nabila (2013) yang dalam penelitiannya menyatakan bahwa komite audit tidak berpengaruh terhadap manjemen laba (earning management).

\subsubsection{Keterbatasan Penelitian}

Nilai dari $\mathrm{R}$ square sebesar 0,031 sehingga menunjukkan bahwa variabel bebas dalam penelitian yaitu proporsi dewan komisaris independen, dan komite audit 
menjelaskan manajemen laba sebesar 3,1\%. Sedangkan sisanya sebesar $96,9 \%$ dipengaruhi oleh variabel lain selain variabel yang digunakan dalam penelitian ini.

\section{Kesimpulan}

Berdasarkan hasil analisis dan pengujian, kesimpulan yang dapat diperoleh dari penelitian ini:

1. Dewan komisaris independen dan komite audit tidak berpengaruh secara simultan terhadap manajemen laba. Hal tersebut sesuai dengan hasil uji koefisien regresi serentak (Uji F) yang menunjukkan nilai $\mathrm{F}$ hitung lebih kecil dari $\mathrm{F}$ tabel, dan dengan nilai determinannya sebesar $3,1 \%$.

2. Secara parsial dewan komisaris independen dan komite audit tidak berpengaruh terhadap manajemen laba. Berdasarkan hasil uji koefisien regresi parsial (uji t) pada variabel dewan komisaris independen dan komite audit menunjukkan nilai signifikasi lebih besar dari 0,05, sehingga disimpulkan kedua variabel dalam penelitian ini tidak berpengaruh terhadap manajemen laba.

\section{Saran}

1. Saran yang diajukan dalam penelitian ini antara lain:

2. Bagi pihak manajemen sebaiknya mengurangi atau meniadakan tindakan manajemen laba dengan alasan apapun. Meskipun keberadaan dewan komisaris dan komite audit dalam suatu badan usaha secara bersama-sama tidak mampu melaksanakan pengawasan dan mencegah tindakan manajemen dalam melakukan kecurangan.

3. Bagi pihak investor dan calon investor hendaknya lebih memperhatikan keberadaan dewan komisaris independen dan komite audit pada suatu perusahaan. Hal tersebut dikarenakan berdasarkan pada hasil analisis penelitian ini yang menyatakan bahwa keberadaan dewan komisaris independen dan komite audit sebagai pihak yang bisa dipercaya kemampuannya dalam melakukan pengawasan ternyata tidak mampu mengurangi tindakan manajemen laba.

4. Penelitian yang akan datang

Diharapkan untuk peneliti yang akan datang agar dapat menambah variabel independen lain untuk menjelaskan pengaruhnya terhadap variabel manajemen laba, sehingga besarnya nilai R square yang dihasilkan dapat lebih besar.

\section{Daftar Pustaka}

Ali, Hasan . 2013. Marketing dan Kasus-Kasus Pilihan. Yogyakarta. CAPS (Center For Academic Publishing Service)

Amstrong dan Philip Kotler. 2003. Manajemen Pemasaran, Edisi Kesembilan.

Jakarta : PT.Indeks Gramedia.

Arianty, Nel. (2014). Pengaruh Budaya Organisasi Terhadap Kinerja Pegawai.Jurnal Manajemen \& Bisnis. VOL 14 (NO. 02), hal. 16937619.

Agus Salim, 2006. Teori dan Paradigma Penelitian Sosial. Yogyakarta: Tiara Wacana.

Ali Hasan (2010 : 13), "Pengaruh word of mouth Marketing terhadap keputusan pembelian." Raynald, Fakultas Ekonomi Manajemen S1. Universitas Maranatha Bandung. 
Creswell, John W. 2015. Penelitian Kualitatif dan Desain Riset: Memilih Diantara Lima Pendekatan. Yogyakarta: Pustaka Pelajar.

Fandy Tjiptono, 1997, Strategi Pemasaran, Edisi 1, Penerbit Andi, Yogyakarta.

H.B. Sutopo (2006). Metodologi Penelitian Kualitatif : Dasar teori dan Terapannya dalam Penelitian Surakarta: Universitas Sebelas Maret.

Kementerian Perindustrian 2013, Permenperin Nomor 55/M-IND/PER/11/2013 tentang Perubahan Peraturan Menteri Perindustrian Nomor 24/MIND/PER/4/2013 tentang Standar Nasional Indonesia (SNI) Mainan Secara Wajib, Jakarta.

Madura,Jeff. 2007. Introductin to Business, Buku 2, Salemba Empat : Jakarta.

Philip Kotler. 2003. Manajemen Pemasaran, Jilid I dan II, PT.Indeks Gramedia, Jakarta .

Purhantara, Wahyu, Metode Penelitian Kualitatif Untuk Bisnis, Yogyakarta: Graha Ilmu, 2010.

Simamora Henry. 2000. Manajemen Pemasaran internasional. Jilid 1 Edisi Cetak 1, Salemba Empat Jakarta. 